\title{
PENGGUNAAN BAHAN AJAR IPA TERPADU TEKANAN DAN SISTEM PERNAPASAN UNTUK MENINGKATKAN LITERASI SAINTIFIK SISWA KELAS VIII SMP NEGERI 8 PADANG
}

\author{
Arnelli Amril ${ }^{1)}$ \\ ${ }^{1)}$ Guru IPA, SMPN 8 Padang \\ Arneliamril1967@gmail.com
}

\begin{abstract}
The integrated science learning is required in the lessons according to the curriculum mandate of 2013. The reason is that all natural phenomena that occur can not be separated, but are a unity. In addition, the integration of scientific literacy in learning needs to be done to improve student learning outcomes. The fact that happened in school shows that integrated science learning has not been applied optimally and the value of scientific literacy test is still low. One solution that can be done is to apply scientifically integrated science-filled teaching materials. The purpose of this study was to determine the students 'scientific literacy and students' cognitive learning outcomes in science learning using integrated materials of pressure materials and respiratory system. The research includes classroom action research (PTK) with two cycles. Each cycle consists of four meetings. The subjects of the study were students of class VIII.B SMPN 8 Padang totaling 28 people. The instruments used in this study are the learning test sheets, the scientific concept appraisal sheets, the scientific process assessment sheets, and the scientific context appraisal sheets. Data analysis techniques used are descriptive statistical analysis, percentage method and graph technique. Based on data analysis that has been done can be presented two research results. First, the application of integrated teaching materials of pressure materials and respiratory system can increase students scientific literacy in learning. This is evident from the improvement of three aspects of scientific literacy from the first cycle to the second cycle: scientific concepts, scientific processes, and scientific contexts. Second, students' cognitive learning outcomes increase from the first cycle with an average score of 75.36 to the second cycle with an average grade of 88.57. This suggests the use of integrated science materials of pressure and respiratory system in science teaching in schools can improve students' cognitive learning outcomes.
\end{abstract}

Keywords : Scientific literacy, Integrated science, Students cognitive, Competence

\section{PENDAHULUAN}

Abad ke-21 ditandai sebagai abad keter bukaan atau abad globalisasi. Artinya kehidupan manusia pada abad ke-21 mengalami perubahan perubahan yang fundamental yang berbeda dengan tata kehidupan dalam abad sebelumnya. Abad ini dikatakan abad yang menuntut kualitas dalam segala usaha dan hasil kerja manusia. Tuntutan-tuntutan yang serba baru tersebut meminta berbagai terobosan dalam berpikir, penyusunan konsep, dan tindakan tindakan. Dengan kata lain diperlukan suatu paradigma baru dalam menghadapi tantangan tantangan yang baru (Etistika, 2016).

Salah satu terobosan baru yang dilakukan pemerintah dalam meningkatkan mutu pendi dikan di Indonesia adalah melakukan evaluasi pengembangan kurikulum pendidikan. Evaluasi pengembangan kurikulum dimulai dari kuri kulum KBK tahun 2004, kurikulum KTSP tahun 2006, dan revisi kurikulum 2013 tahun 2016. Berdasarkan hasil evaluasi, kurikulum 2013 ber tujuan untuk mempersiapkan manusia Indonesia agar memiliki kemampuan hidup sebagai pribadi dan warga negara yang beriman, produktif, kreatif, inovatif, dan afektif serta mampu ber kontribusi pada kehidupan bermasyarakat, berbangsa, bernegara, dan peradaban dunia (Kemendikbud, 2013).

Dalam dunia pendidikan literasi menjadi sarana bagi siswa untuk mengenal, memahami, dan menerapkan ilmu yang didapatkannya dibangku sekolah. Literasi dapat menunjang kemampuan siswa dalam sains dan teknologi agar siswa dapat menerapkan dan menerima ilmu yang didapatnya dalam lingkungan sehari hari dan pembelajaran. Literasi saintifik juga diperlukan dalam pembelajaran IPA. 
Literasi saintifik dalam pembelajaran terdapat tiga kerangka penilaian yaitu, konsep saintifik (scientific concepts), proses saintifik (scientific process), dan konteks saintifik (scien tific context). Konsep-konsep saintifik dalam pembelajaran IPA terkait dengan gejala Fisika, Kimia, Biologi, dan Ilmu Bumi dan Antariksa. Proses saintifik yang berpusat pada kemampuan untuk memperoleh informasi, menafsirkan dan bertindak berdasarkan bukti. Ketiga, konteks saintifik yang berhubungan dengan penerapan pengetahuan saintifik dan penggunaan terapan saintifik dalam pembelajaran IPA (Budi, 2016).

Pembelajaran IPA terpadu dalam kuri kulum 2013 mengutamakan keterpaduan antara materi Biologi, Fisika, dan Kimia. Keterpaduan akan membuat pembelajaran IPA akan lebih optimal (Zuhdan, 2012). Disisi lain, pembelajar an IPA terpadu, diharapkan siswa dapat mem bangun pengetahuannya melalui proses saintifik, bekerja sama dalam kelompok, belajar berinter aksi dan berkomunikasi, serta bersikap saintifik. keberhasilan pembelajaran IPA terpadu akan lebih optimal jika perencanaan mempertimbang kan kondisi dan potensi siswa mencakup minat, bakat, kebutuhan, kemampuan.

Namun, kenyataan yang ditemukan di SMP Negeri 8 Padang belum sesuai dengan yang diharapkan. Dari hasil studi awal diperoleh empat kenyataan dalam pembelajaran IPA. Ke empat kenyataan tersebut adalah pelaksanaan pembelajaran IPA terpadu belum dilaksanakan secara optimal, keterpaduan IPA dalam buku teks, nilai literasi siswa, dan hasil belajar siswa.

Kenyaatan Pertama adalah pelaksanaan pembelajaran IPA terpadu di kelas VIII SMP Negeri 8 Padang belum optimal. Hal ini dilihat dari guru yang mengalami kesulitan dalam mengkaitkan materi Fisika, Kimia, dan Biologi secara utuh sehingga keterpaduan IPA belum tergambar dengan baik. Disisi lain, guru juga mengalami kesulitan dalam menerapkan model keterpaduan secara utuh. Kendala yang dihadapi guru dalam menerapkan model keterpaduan adalah materi IPA yang masih diajarkan oleh guru yang berasal dari latar keilmuan Fisika, Kimia, dan Biologi.

Kemudian, kenyataan kedua adalah ting kat keterpaduan IPA dalam buku tesk IPA ter padu masih kurang. Hal ini dilihat dari analisis keterpaduan materi IPA dari delapan buku teks IPA terpadu yang telah dianalisis diperoleh nilai rata-rata tingkat keterpaduan materi IPA adalah 39,72. Dari hasil tersebut dapat dikatakan bahwa materi yang disajikan adalah masih terpisah pisah antara materi Biologi, Fisika, dan Kimia sehingga masih minim mencerminkan keterpaduan IPA.

Selanjutnya, kenyataan ketiga adalah nilai literasi saintifik siswa. Dari hasil tes literasi siswa kelas VIIIB SMP Negeri Padang di peroleh nilai rata-rata 59,64 dan berada pada kategori rendah. Disisi lain, dapat dilihat dari laporan PISA yang diketahui bahwa hasil literasi sains siswa di Indonesia belum memuaskan. Skor literasi siswa tahun 2009 adalah 383 dengan skor tertinggi 575. Siswa Indonesia menempati peringkat 57 dari 65 negara peserta (Gurria, 2010). Pada tahun 2012, skor literasi sains siswa Indonesia adalah 382 dengan skor tertinggi 501. Siswa Indonesia menempati pe ringkat 64 dari 65 negara peserta (Gurria, 2014). Dari kedua hasil laporan PISA ini dapat dikemukakan bahwa literasi sains siswa SMP di Indonesia masih rendah (Asrizal, 2017).

Terakhir, Kenyataan keempat adalah hasil belajar siswa yang belum optimal. Hasil belajar siswa yang belum optimal dilihat dari hasil nilai ulangan harian kompetensi dasar 3.7 siswa kelas VIIIB SMP Negeri 8 Padang. Berdasarkan hasil ulangan harian siswa didapatkan nilai rata-rata 71,40 . Hal ini menunjukkan bahwa nilai ratarata ulangan harian siswa belum mencapai kriteria ketuntasan minimum (KKM) yaitu $\geq 80$ dan tergolong belum tuntas.

Kondisi nyata yang ditemukan tidak sesuai dengan yang diharapkan sehingga timbul masalah dalam pembelajaran IPA terpadu. Adanya upaya untuk mengatasi permasalahan ini penting untuk dilakukan. Sebagai alternatif solusi untuk memecahkan masalah ini adalah menerapkan bahan ajar IPA terpadu bermuatan literasi saintifik untuk SMP kelas VIII.

Berdasarkan solusi tersebut terdapat tiga kajian teori dasar yang perlu ada. Pertama, kajian teori mengenai bahan ajar. Bahan ajar merupakan pedoman bagi guru maupun siswa dalam proses pembelajaran. Bahan ajar merupa kan segala bahan yang disusun secara siste matis yang menampilkan sosok utuh dari kompetensi yang akan dikuasai siswa dan di gunakan dalam proses pembelajaran dengan tujuan perencanaan dan penelaahan implemen tasi pembelajaran (Andi, 2011). Pengertian lain dari bahan ajar adalah bahan atau materi yang disusun oleh guru secara sistematis yang diguna kan siswa dalam pembelajaran (Soegiranto dan Oni, 2013). Jadi bahan ajar merupakan sesuatu 
yang sangat penting dalam menunjang keber hasilan pembelajaran yang berperan sebagai perantara antara guru dan siswa berinteraksi dalam pembelajaran.

Pembelajaran IPA terpadu menggunakan bahan ajar memberikan manfaat bagi siswa. Manfaat penggunaan bahan ajar bagi siswa yaitu: 1) kegiatan pembelajaran menjadi lebih menarik, 2) siswa akan lebih banyak mendapat kan kesempatan untuk belajar secara mandiri dan mengurangi ketergantungan terhadap keha diran guru, dan 3) siswa juga akan mendapatkan kemudahan dalam mempelajari setiap kompe tensi yang harus dikuasainya. Disisi lain, peng gunaan bahan ajar dalam proses pembelajaran dapat membuat guru menyampaikan informasi secara kongkrit kepada siswa.

Selanjutnya, kajian teori kedua adalah pembelajaran IPA terpadu. Pendidikan IPA ber kaitan dengan cara mencari tahu tentang alam secara sistematis, sehingga IPA bukan hanya penguasaan kumpulan pengetahuan yang berupa fakta-fakta, konsep-konsep, atau prinsip-prinsip saja tetapi juga merupakan suatu proses pene muan (BSNP, 2006). IPA merupakan pemaham an tentang pentingnya mempelajari gejala-gejala di alam yang dibutuhkan untuk dapat memecah kan masalah di lingkungan agar dapat menjadi kan manusia lebih bermakna (Trianto, 2012). Pemahaman IPA yang dimiliki siswa akan membantu siswa untuk dapat mengembangkan pengetahuan, sikap, dan keterampilan sehingga dapat memahami gejala-gejala alam yang terjadi di kehidupan.

Pembelajaran terpadu merupakan pende katan pembelajaran yang melibatkan beberapa bidang studi untuk memberikan pengalaman yang bermakna dan mendalam bagi siswa. Pem belajaran terpadu merupakan pendekatan belajar mengajar yang memperhatikan dan menyesuai kan dengan tingkat perkembangan anak didik (developmentally appropriate practical). Pende katan yang berangkat dari teori pembelajaran yang menolak drill-system sebagai dasar pembentukan pengetahuan dan struktur inteklek tual anak (Iif, 2014).

Kajian teori ketiga adalah tentang literasi saintifik siswa. Literasi saintifik adalah suatu ilmu pengetahuan dan pemahaman mengenai konsep dan proses saintifik yang akan memung kinkan seseorang untuk membuat suatu keputus an dengan pengetahuan yang dimilikinya, serta turut terlibat dalam hal kenegaraan, budaya dan pertumbuhan ekonomi (National Science Educa tion Standards, 1996). Defenisi lain dari literasi saintifik adalah literasi saintifik menuntut setiap orang untuk sadar akan ilmu pengetahuan dan isu-isu publik. Dalam hal ini, konsep saintifik diperlukan untuk memahami alam dan perubahannya, penilaian aplikasinya pada bidang kesehatan, lingkungan dan teknologi.

Adanya literasi saintifik dalam pembelaja ran IPA terpadu diharapkan dapat meningkatkan kemampuan siswa dalam membaca, dan meng gali informasi serta dalam menerapkan dan me nemukan konsep-konsep, proses dan konteks saintifik. Dalam hal ini, konsep saintifik diperlukan untuk memahami alam dan peruba hannya, penilaian aplikasinya pada bidang kesehatan, lingkungan dan teknologi. Selanjut nya, proses saintifik diperlukan untuk mening katkan kemampuan untuk menafsirkan dan bertindak. Kemudian, konteks saintifik juga di perlukan untuk penerapan pengetahuan saintifik (Miller, 1983).

Penelitian yang dilakukan memiliki dua tujuan utama. Pertama, menentukan literasi saintifik siswa dalam pembelajaran IPA meng gunakan bahan ajar IPA terpadu tekanan dan sistem pernapasan. Kedua, menentukan hasil belajar kognitif siswa dalam pembelajaran IPA menggunakan bahan ajar IPA terpadu tekanan dan sistem pernapasan.

\section{METODE PENELITIAN}

Penelitian yang dilaksanakan merupakan Penelitian Tindakan Kelas (PTK). PTK merupa kan suatu pencermatan terhadap belajar berupa sebuah tindakan yang sengaja dimunculkan dan terjadi dalam sebuah kelas secara bersama. Tindakan tersebut diberikan oleh guru dengan arahan dari guru yang akan dilakukan oleh siswa (Suharsimi, 2002). Rancangan PTK yang di gunakan adalah daur ulang yang dikenal dengan istilah siklus. PTK diawali dengan perencanaan (planing), penerapan tindakan (action), obser vasi proses dan evaluasi hasil tindakan (obser vation and evaluation) dan melakukan refleksi (reflection).

Ada beberapa hal yang perlu disiapkan pada penelitian ini, antara lain: 1) menelaah kurikulum dan silabus mata pelajaran IPA kelas VIII SMP untuk mengetahui kompetensi dasar dari indikator yang ingin dicapai, 2) merancang bahan ajar IPA terpadu pada materi tekanan pada zat dan sistem pernapasan manusia, 3) me rancang RPP untuk masing-masing pertemuan pada materi tekanan pada zat dan sistem per 
napasan manusia, 4) merancang lembaran obser vasi aktivitas siswa dalam pembelajaran untuk tiap pertemuan, 5) menyususn kisi-kisi soal dan membuat evaluasi pembelajaran untuk mengu kur penguasaan siswa pada setiap siklus. Pelak sanaan penelitian ini selama dua bulan. Penelitian ini terdiri dari dua KD yaitu satu bulan untuk KD 3.8 dan satu bulan untuk KD 3.9. Semua siklus dilaksanakan selama delapan minggu. Penelitian ini dilaksanakan di SMP Negeri 8 Padang.

Subjek penelitian adalah siswa kelas VIIIB SMP N 8 Padang. Jumlah siswa kelas VIIIB adalah 28 orang yang terdiri dari 12 orang laki-laki dan 16 orang perempuan. Dari pengalaman peneliti selama mengajar dikelas VIIIB banyak didapatkan karakteristik siswa yang perlu diperbaiki diantaranya, kebanyakan siswa kurang fokus dalam belajar, disiplin dalam belajar masih kurang, disiplin dalam mengerja kan latihan dan kegiatan masih kurang, dan kurang disiplin dalam mengumpulkan tugas.

Instrumen yang digunakan dalam penelitian ini adalah lembar tes hasil belajar dan lembar penilaian literasi saintifik. Instrumen tes hasil belajar ini dibuatkan berdasarkan indikator ketercapaian KD materi yang diujikan. Tes hasil belajar dilakukan setelah materi setiap KD selesai dan dilakukan tes pada subjek penelitian dari penelitian ini. Lembar penilaian literasi saintifik terdiri dari tiga jenis, yaitu lembar penilaian konsep saintifik, lembar penilaian proses saintifik meliputi: kinerja eksperimen dan laporan eksperimen, dan lembar penilaian konteks saintifik.

Teknik analisis data pada penelitian ini ada tiga yaitu, analisis statistik deskriptif, metode persentase, dan teknik grafik. Statistik deskriptif merupakan bidang ilmu statistik yang mencangkup cara-cara pengumpulan data, penyusunan dan penyajian data suatu penelitian. Teknik persentase digunakan untuk menganalisis data aktivitas siswa dalam proses pembelajaran. Untuk menentukan persentase aktivitas siswa digunakan rumus persamaan 1 .

$$
P=\frac{F}{N} \times 100 \%
$$

$\mathrm{P}$ adalah persentase aktivitas siswa, $\mathrm{F}$ adalah jumlah siswa yang terlibat dan $\mathrm{N}$ adalah jumlah siswa yang hadir. Untuk menentukan persentase rata-rata aktivitas siswa tiap pertemuan diperlihatkan oleh persamaan 2 .

$$
P_{R}=\frac{\Sigma P}{N} \times 100 \%
$$

$\mathrm{P}_{\mathrm{R}}$ adalah persentase rata-rata aktivitas siswa tiap pertemuan, $\mathrm{P}$ adalah persentase aktivitas siswa, dan $\mathrm{N}$ adalah jumlah aktivitas yang di amati dalam tiap pertemuan. Disisi lain, persentase rata-rata aktivitas siswa dalam suatu siklus diperlihatkan oleh persamaan 3 .

$$
P_{S}=\frac{\Sigma P_{R}}{N_{A}} \times 100 \%
$$

$\mathrm{P}_{\mathrm{S}}$ adalah persentase rata-rata aktivitas siswa tiap siklus, $P_{R}$ adalah persentase aktivitas siswa tiap pertemuan, $\mathrm{N}_{\mathrm{A}}$ adalah jumlah aktivitas yang diamati tiap siklus. Untuk menentukan kriteria kurang $(\mathrm{K})$ dari 1 sampai 25 , sedang (S) dari 26 sampai 50, baik (B) dari 51 sampai 75, dan baik sekali (BS) dari 76 sampai 100. Disisi lain, analisis grafik digunakan untuk melihat gambaran persentase aktivitas untuk setiap macam aktivitas dalam setiap pengamatan. Gambaran aktivitas ini dilukiskan dalam bentuk grafik batang.

\section{HASIL PENELITIAN DAN PEMBAHASAN}

\section{Hasil Penelitian}

Secara umum, ada dua hasil utama dari penelitian siklus pertama dan siklus kedua. Hasil penelitian tersebut meliputi nilai literasi saintifik meliputi: konsep saintifik, proses saintifik, dan konteks saitifik dan hasil belajar kognitif siswa. Penelitian yang telah dilakukan merupakan pene litian menggunakan Bahan Ajar IPA terpadu bermuatan literasi saintifik siswa kelas VIII. Dari analisis data siklus pertama dan siklus kedua dapat dilihat peningkatan hasil penelitian. Peningkatan hasil penelitian dari siklus pertama ke siklus kedua dapat dilihat dengan cara membandingkan hasil yang diperoleh untuk setiap siklus yang telah dilakukan.

Pada penilaian konsep saintifik siswa akan diminta untuk menjawab setiap pertanyaan pada kolom konsep saintifik yang ada di dalam bahan ajar sebagai tugas. Indikator yang diguna kan dalam penilaian konsep saintifik ada empat, yaitu kebenaran konsep, kejelasan konsep, hu bungan antar konsep, dan mengemukakan fakta. Pada aspek konsep saintifik terdapat peningkat an nilai konsep saintifik siswa dari siklus pertama ke siklus kedua.

Dari analisis data yang didapatkan, dapat diplot grafik peningkatan yang terjadi pada aspek konsep saintifik siswa dari siklus pertama ke siklus kedua. Grafik tersebut menunjukkan semua indikator penilaian konsep saintifik. Hasil data peningkatan literasi saintifik pada aspek konsep saintifik dapat dilihat pada Gambar 1. 


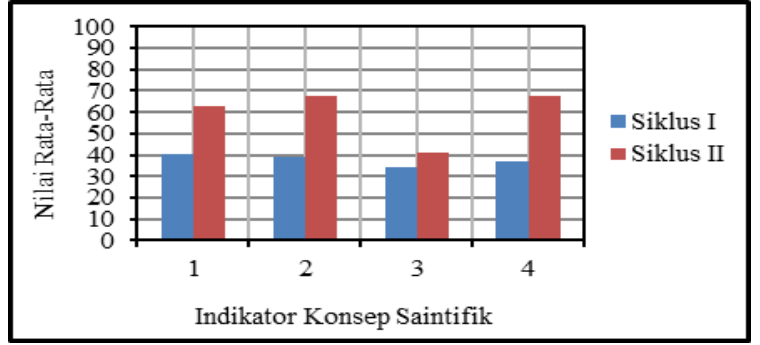

Gambar 1. Data Konsep Saintifik Siswa Siklus Pertama dan Siklus Kedua

Berdasarkan Gambar 1, dapat diinter pretasikan peningkatan tiap-tiap indikatornya. Pertama, indikator kebenaran konsep cenderung meningkat dari siklus pertama dengan nilai rata rata 40,18 ke siklus kedua dengan nilai rata-rata 62,50. Kedua, indikator kejelasan konsep me ningkat dari siklus pertama dengan nilai rata rata 38,69 ke siklus kedua dengan nilai rata-rata 67,86. Ketiga, indikator hubungan antar konsep meningkat dari siklus pertama dengan nilai rata rata 34,53 ke siklus kedua dengan nilai rata-rata 41,07. Keempat, indikator mengemukakan fakta mengalami peningkatan dari siklus pertama ke siklus kedua dari nilai rata-rata 36,90 sampai 67,86 . Oleh karena itu, semua indikator konsep saintifik meningkat dari siklus pertama ke siklus kedua dengan kriteria sedang dan baik.

Pada aspek proses saintifik yang dinilai pada siklus pertama dan kedua yaitu kinerja eksperimen dan laporan penyelidikan. Dari analisis data aspek proses saintifik siswa di peroleh bahwa terjadi peningkatan dari siklus pertama ke siklus kedua. Indikator kinerja eksperimen meliputi: menyiapkan alat, menyu sun alat, menggunakan alat, mengambil data, menempatkan data pada tabel, dan mengem balikan alat.

Hasil peningkatan kinerja eksperimen dapat diplot grafik. Grafik menggambarkan peningkatan nilai rata-rata indikator kinerja eksperimen. Hasil plot peningkatan nilai kinerja eksperimen dapat dilihat pada Gambar 2.

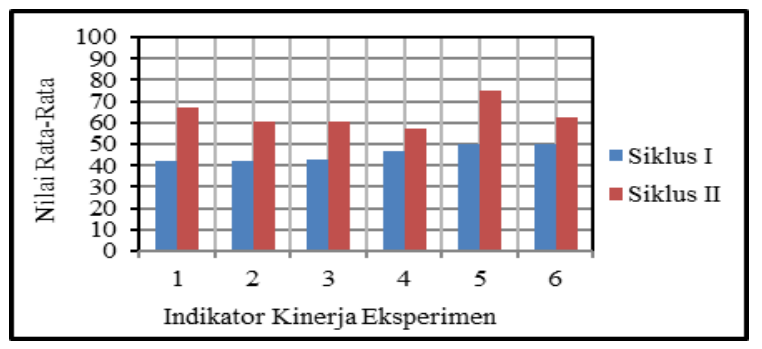

Gambar 2. Data Kinerja Eksperimen Siswa Siklus Pertama dan Siklus Kedua
Dari Gambar 2, dapat dilihat bahwa dari aspek kinerja eksperimen telah menunjukkan peningkatan tiap-tiap indikatornya. Pertama, indikator menyiapkan alat cenderung meningkat dari siklus pertama dengan nilai rata-rata 41,97 ke siklus kedua dengan nilai rata-rata 66,96. Kedua, indikator menyusun alat meningkat dari siklus pertama dengan nilai rata-rata $42,41 \mathrm{ke}$ siklus kedua dengan nilai rata-rata 60,71. Ketiga, indikator menggunakan alat meningkat dari siklus pertama dengan nilai rata-rata 42,86 ke siklus kedua dengan nilai rata-rata 60,71. Keempat, indikator mengambil data mengalami peningkatan dari siklus pertama ke siklus kedua dari nilai rata-rata 46,43 sampai 57,14. Kelima, indikator menempatkan data pada tabel meningkat dari nilai rata-rata 50,00 sampai 75,00. Keenam, indikator mengembalikan alat meningkat dari nilai rata-rata 37,50 sampai 62,50 . Dengan demikian, semua indikator kinerja eksperimen meningkat dari siklus pertama ke siklus kedua dengan kriteria baik.

Selain kinerja eksperimen, proses saintifik siswa juga dapat dinilai melalui laporan eksperimen. Berdasarkan data yang diperoleh pada siklus pertama dan kedua didapatkan bahwa hasil pencapaian penelitian pada laporan eksperimen meningkat dari sebelumnya. Penilaian laporan penyelidikan menggunakan lima indikator yaitu: 1) tujuan eksperimen, 2) teori dasar, 3) prosedur kerja, 4) data dan pengolahan, dan 5) kesimpulan.

Grafik peningkatan hasil aspek laporan eksperimen diperoleh dari analisis data. Grafik tersebut menggambarkan peningkatan masingmasing indikator penilaian laporan eksperimen. Hasil plot peningkatan nilai laporan eksperimen dapat dilihat pada Gambar 3.

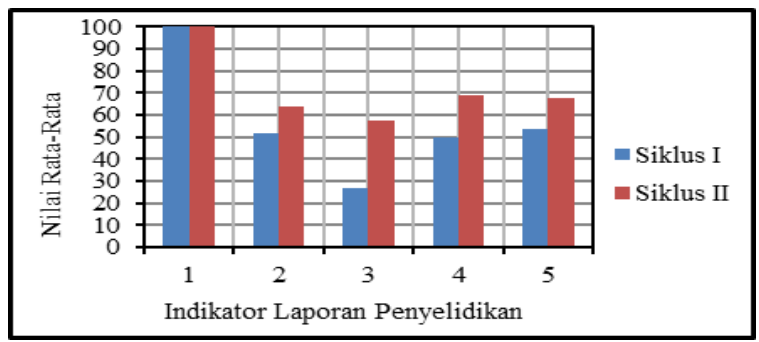

Gambar 3. Data Laporan Penyelidikan Siswa Siklus Pertama dan Siklus Kedua

Gambar 3 menunjukkan peningkatan tiaptiap indikatornya untuk aspek laporan eksperimen yang dapat dijelaskan sebagai berikut. Pertama, indikator tujuan eksperimen dalam siklus pertama dan kedua sudah mencapai 
nilai yang baik dengan perolehan nilai 100 . Kedua, indikator teori dasar meningkat dari siklus pertama ke arah yang lebih baik pada siklus kedua dengan nilai rata-rata 51,79 menjadi 64,29. Ketiga, indikator prosedur kerja meningkat dari siklus pertama dengan nilai ratarata 26,79 ke siklus kedua dengan nilai rata-rata 57,14 . Keempat, indikator data dan pengolahan mengalami peningkatan dari siklus pertama ke siklus kedua yaitu dari nilai rata-rata 50,00 menjadi 68,75 . Kelima, indikator kesimpulan cenderung meningkat dari siklus pertama ke siklus kedua dengan nilai rata-rata 53,57 sampai 67,86. Jadi, secara keseluruhan indikator laporan penyelidikan meningkat dari siklus pertama ke siklus kedua dengan kriteria baik.

Pada aspek konteks saintifik terdapat peningkatan nilai konteks saintifik siswa dari siklus pertama ke siklus kedua. Hal ini dilihat dari nilai rata-rata lima indikator penilaian konteks saintifik. Kelima indikator tersebut meliputi: kerapian tulisan, kelengkapan aplikasi, kebenaran materi, kesesuaian aplikasi, dan referensi materi.

Berdasarkan data yang telah didapatkan, dapat diplot grafik peningkatan nilai konteks saintifik. Grafik tersebut menggambarkan peningkatan nilai rata-rata setiap indikator tugas konteks saintifik. Hasil plot peningkatan aspek konteks saintifik siswa dari siklus pertama dan siklus kedua dapat dilihat pada Gambar 4.

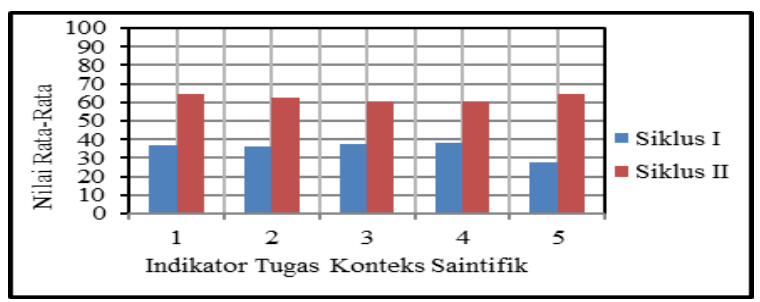

Gambar 4. Data Tugas Konteks Saintifik Siswa Siklus Pertama dan Siklus Kedua

Dari Gambar 4, dapat dilihat bahwa dari aspek konteks saintifik telah menunjukkan peningkatan tiap-tiap indikatornya. Indikator kerapian tulisan meningkat dari siklus pertama ke siklus kedua dengan nilai rata-rata 36,01 sampai 64,29. Indikator kelengkapan aplikasi meningkat dari siklus pertama ke siklus kedua dengan nilai rata-rara 36,01 sampai 62,50 . Indikator kebenaran materi mengalami peningkatan dari siklus pertama ke siklus kedua dengan nilai rata-rata 37,20 sampai 60,71 . Indikator kesesuaian aplikasi meningkat dari siklus pertama ke siklus kedua dengan nilai rata-rata
38,10 sampai 60,71. Indikator referensi materi meningkat dari siklus pertama ke siklus kedua dengan nilai rata-rata 27,68 menjadi 64,29. Oleh sebab itu, secara keseluruhan indikator tugas konteks saintifik meningkat dari siklus pertama ke siklus kedua dengan kriteria baik.

Disisi lain, aspek pengetahuan juga dibanding kan antara siklus pertama dan siklus kedua untuk melihat peningkatan hasil belajar kognitif siswa. Data nilai kognitif siswa pada siklus pertama diperoleh dari hasil tes akhir dengan melakukan postes KD 3.8 tentang tekanan pada zat. Selanjutnya, hasil belajar kognitif siswa siklus kedua diperoleh dari tes akhir dengan melakukan postes KD 3.9 tentang sistem pernapasan pada manusia. Tes akhir yang diberikan untuk kedua siklus berupa tes objektif dengan 4 pilihan jawaban sebanyak 25 soal. Tes akhir diberikan kepada kelas penelitian dengan jumlah siswa 28 orang.

Analisis data untuk setiap parameter statistik dilakukan pada setiap siklus. Parameter statistik yang dibandingkan adalah nilai ratarata, varians, standar deviasi, nilai terendah, nilai tertinggi dan rentangan nilai. Berdasarkan analisis data, dapat dideskripsikan peningkatan hasil belajar kognitif siswa dari siklus pertama ke siklus kedua ke dalam bentuk tabel. Deskripsi hasil belajar kognitif siswa dari siklus pertama ke siklus kedua diperlihatkan pada Tabel 1.

Tabel 1. Nilai Parameter Statistik Deskriptif dari Hasil belajar Kognitif Siswa

\begin{tabular}{|l|l|c|c|}
\hline No & $\begin{array}{l}\text { Parameter } \\
\text { Statistik }\end{array}$ & $\begin{array}{c}\text { Nilai } \\
\text { Siklus I }\end{array}$ & $\begin{array}{c}\text { Nilai } \\
\text { Siklus II }\end{array}$ \\
\hline 1. & Rata-rata & 75,36 & 88,57 \\
\hline 2. & Varians & 102,24 & 63,66 \\
\hline 3. & Standar deviasi & 10,11 & 7,98 \\
\hline 4. & Nilai terendah & 60,00 & 72,00 \\
\hline 5. & Nilai tertinggi & 96,00 & 100,00 \\
\hline 6. & Rentangan Nilai & 36,00 & 28,00 \\
\hline
\end{tabular}

Dari data pada Tabel 1, dapat dideskripsi kan peningkatan hasil belajar kognitif siswa dari siklus pertama ke siklus kedua. Hasil belajar kognitif siswa meningkat dari nilai rata-rata 75,36 menjadi 88,57. Penurunan nilai standar deviasi tes kedua menyatakan bahwa kenaikan nilai siswa tidak hanya terjadi pada beberapa orang siswa saja, tetapi juga diikuti oleh hampir semua siswa. Hal itu bisa terlihat dari nilai terendah yang didapat siswa pada saat mengi kuti postes siklus pertama adalah 60 dan pada saat mengikuti postes siklus kedua adalah 72 . Nilai tertinggi pada masing-masing tes juga 
mengalami peningkatan dari 96 menjadi 100 . Jadi, hasil belajar kognitif siswa meningkat dari siklus pertama ke siklus kedua dengan kriteria baik sekali.

Ketuntasan hasil belajar kognitif siswa mengalami peningkatan dari siklus pertama ke siklus kedua. Persentase ketuntasan hasil belajar kognitif siswa siklus pertama adalah 28,57\% sedangkan Persentase ketuntasan hasil belajar kognitif siswa pada siklus kedua yaitu $85,71 \%$. Ini bearti ketuntasan hasil belajar siswa pada siklus kedua sudah tercapai secara optimal dan terjadi peningkatan dari siklus pertama ke siklus kedua.

\section{Pembahasan}

Hasil penelitian ini dapat dijadikan dasar pengembangan bahan ajar IPA terpadu bermuatan literasi saintifik. Hal ini dilihat dari hasil yang telah dicapai, yang belum dicapai, serta kendala-kendala yang dihadapi selama proses pelaksanaan dari siklus pertama dan siklus kedua. Hasil yang telah dicapai dalam penelitian siklus pertama ini adalah: 1) kebenaran dalam membuat konsep saintifik sudah dibilang cukup baik, 2) dalam melakukan penyelidikan dan menempatkan data pada tabel yang disediakan sudah cukup dimengerti, 3) dalam membuat laporan penyelidikan, tujuan percobaan pada laporan sudah dibuat sangat baik dan sesuai dengan percobaan yang dilakukan, dan 4) dalam kegiatan konteks saintitik kerapian tulisan yang dibuat cukup baik.

Penelitian yang belum tercapai pada siklus pertama diantaranya: pada pengerjaan tugas-tugas siswa pada bahan ajar banyak diantara siswa yang dalam berkelompok tidak ikut berpartisipasi, tugas-tugas yang diberikan dibuat tidak lengkap, laporan eksperimen pada kegiatan proses saintifik masih menyalin katakata dibahan ajar, konsep saintifik yang dipaparkan pada kegiatan konsep saintifik hanya sedikit dan yang ada di dalam bahan ajar saja, kegiatan konteks saintifik masih banyak siswa yang belum mengetahui apa saja aplikasi dalam kehidupan pada materi tersebut dan siswa masih dibimbing terlebih dahulu apa saja yang akan di buat beserta contohnya.

Dalam penelitian tindakan kelas ini, pada siklus pertama terdapat beberapa kendala yang dihadapi selama penelitian yaitu: 1) Penggunaan alat pada kinerja eksperimen belum optimal, 2) waktu yang terbatas sehingga membuat kegiatan eksperimen berjalan sedikit lama dan tidak sempat untuk persentasi di akhir kegiatan eks-perimen, 3) siswa belum terlalu mengenal me-ngenai konsep saintifik, proses saintifik, dan konteks saintifik.

Kendala yang dihadapi pada siklus pertama perlu dilakukan tindakan revisi untuk memperoleh hasil yang lebih baik. Revisi pada tidakan siklus pertama diantaranya: mengoptimalkan latihan dan mencek pemahaman siswa, memberikan contoh fakta dan konsep dalam kehidupan terkait dengan materi, mendemonstrasikan penggunaan alat, cara pengambilan data hasil eksperimen, memberi contoh cara menyimpulkan hasil eksperimen yang baik, memberikan contoh konteks yang relevan dengan materi, dan memperkenalkan teknik-teknik penulisan yang baik.

Hasil yang telah dicapai pada siklus kedua adalah hampir semua indikator mengalami peningkatan nilai literasi saintifik untuk setiap aspek konsep saintifik, proses saintifik, dan konteks saintifik serta hasil belajar kognitif siswa. Namun, hasil yang belum tercapai pada siklus kedua dari data yang diperoleh adalah nilai rata-ratanya $<80$ atau berada di bawah KKM untuk aspek nilai literasi saintifik.

Harapan untuk mendapatkan hasil yang sempurna dalam penelitina merupakan hal yang tidak mudah untuk diwujudkan. Meskipun pada siklus pertama telah dilakukan revisi terhadap kelemahan-kelamahan yang terjadi namun pada siklus kedua masih terdapat kendala-kendala yang dihadapi. Kendala-kendala yang dihadapi tersebut terdapat pada hasil nilai rata-rata peningkatan dari siklus pertama ke kedua yang masih berada di bawah KKM untuk tiga aspek literasi saintifik siswa.

Kendala pertama, nilai rata-rata untuk tugas konsep saintifik yang masih berada di bawah KKM. Hal ini disebabkan siswa yang kurang memperhatikan penjelasan dari guru mengenai pembuatan tugas konsep saintifik meski telah diberikan contoh dari tugas konsep saintifik yang sesuai dengan penilaian. Solusi dari kendala ini yang dapat dilakukan adalah dengan guru harus tegas dan bisa menumbuhkan semangat dan motivasi untuk bertanggung jawab dengan tugas yang telah diberikan kepada siswa.

Kendala kedua, nilai rata-rata untuk tugas proses saintifik baik kinerja eksperimen dan laporan eksperimen masih berada di bawah KKM. Hal ini disebabkan siswa kurang memperhatikan penjelasan dari guru mengenai demonstrasi kinerja eksperimen dan pembuatan 
laporan meski telah diberikan demonstrasi sebelum eksperimen dan contoh laporan yang sesuai dengan penilaian. Solusi dari kendala ini dapat dilakukan guru harus tegas dan mem berikan gambaran bahwa setiap penilaian akan berhubungan dengan nilai yang diperoleh siswa.

Kendala ketiga, nilai rata-rata untuk tugas konteks saintifik belum mencapai KKM. Hal ini disebabkan siswa yang kurang memperhatikan penjelasan dari guru mengenai pembuatan tugas konteks saintifik meski telah diberikan contoh dari tugas konteks saintifik yang sesuai dengan penilaian. Solusi dari kendala ini yang dapat dilakukan adalah dengan guru harus bisa menumbuhkan semangat dan motivasi untuk bertanggung jawab dengan tugas yang telah diberikan.

\section{KESIMPULAN}

Dari hasil analisis data yang telah dilakukan dapat dikemukakan dua kesimpulan dari penelitian ini. Pertama, penerapan bahan ajar IPA terpadu materi tekanan dan sistem pernapasan dapat meningkatkan literasi saintifik siswa dalam pembelajaran. Hal ini terlihat dari peningkatan tiga aspek literasi saintifik dari siklus pertama ke siklus kedua yaitu: konsep saintifik dari nilai rata-rata 37,58 sampai 59,82, proses saintifik berupa kinerja eksperimen dari nilai rata-rata 43,53 sampai 63,84 , proses saintifik berupa laporan penyelidikan dari nilai rata-rata 56,43 sampai 71,61 , dan konteks saintifik dari nilai rata-rata 35,00 sampai 62,50 sehingga semua aspek peningkatan literasi saintifik berada pada kriteria baik. Kedua, penggunaan bahan ajar IPA terpadu materi tekanan dan sistem pernapasan dalam pembelajaran dapat meningkatkan hasil belajar kognitif siswa. Hal ini dapat dilihat dari pening katan nilai rata-rata hasil belajar siswa dari siklus pertama ke siklus kedua dengan nilai rata-rata 75,36 menjadi 88,57 .

\section{DAFTAR PUSTAKA}

Andi Prastowo. 2011. Panduan Kreatif Membuat Bahan Ajar Inovatif: Menciptakan Metode Pembelajaran yang Menarik dan Menyenangkan. Yogyakarta: Diva Press.

Asrizal, Festiyed, \& Sumarmin, R. (2017). Analisis Kebutuhan Pengembangan Bahan Ajar Ipa Terpadu Bermuatan Literasi Era Digital Untuk Pembelajaran Siswa Smp Kelas Viii. Jurnal Eksakta Pendidikan (Jep), 1(1), 1-8. Retrieved From http://jep.ppj.unp.ac.id/index.php/jep/a rticle/view/27

BSNP. 2006. Standar Isi Mata Pelajaran IPA SMP/MTs. Jakarta: Balitbang.

Budi Utami. 2016. Scientific Literacy In Science Lesson. Prosiding ICTTE FKIP UNS, Volume 1(I), hlm. 125-133.

Depdiknas. 2008. Panduan Umum Pengembangan Bahan Ajar. Jakarta: Depdiknas.

Etistika Yuni Wijaya, dk. 2016. Transformasi Pendidikan Abad 21 sebagai Tuntutan Pengembangan Sumber Daya Manusia Di Era Global. Prosiding Seminar Nasional Pendidikan Matematika UKM, Volume 1, hlm. 263-278.

Gurria, Angel. 2010. PISA 2009 Results: What Students Know and Can Do. Student Performance in Reading, Mathematics and Science. Programme for International Students Assessment, OECD.

Gurria, Angel. 2014. PISA 2012 Results in Focus: What 15-year-olds know and what they can do with what they know. Programme for International Students Assessment, OECD.

Iif Khoiru Ahmadi, dkk. 2011. Strategi Pembelajaran Sekolah Terpadu. Jakarta: Prestasi Pustakaraya.

Kemendikbud. 2013. Peraturan Menteri Pendidikan dan Kebudayaan Nomor 69 Tahun 2013. Jakarta.

Miller, Jon D. 1983. Scientifik Lite racy: A Conceptual And Empirical Re view. The MIT Press on Behalf of Ame rican Academy of Arts \& Sciences, 112 (II), 29-48.

Soegiranto dan Oni Arlitasari. 2013. Pengembangan Bahan Ajar IPA Terpadu Berbasis Saling Temas dengan Tema Biomassa Sumber Energi Alternatif Terbarukan. Surakarta: Universitas Sebelas Maret.

Suharsimi Arikunto. 2002. Dasar-Dasar Evaluasi Pendidikan (edisi revisi). Jakarta: Bumi Aksara.

Trianto. 2012. Model Pembelajaran Terpadu. Jakarta:Bumi Aksara.

Zuhdan Kun Prasetyo. 2012. Pengembangan Perangkat Pembelajaran Sains Terpadu untuk Meningkatkan Kognitif, Keterampilan Proses, Kreativitas Serta Menerapkan Konsep Ilmiah Peserta Didik SMP. Yogyakarta: UNY. 